Zabytkoznawstwo i Konserwatorstwo XLIV, Toruń 2013

\author{
Halina Turska
}

Zakład Historii Sztuki Średniowiecznej i Nowożytnej WSP UMK

\title{
Veraicon w średniowiecznym Toruniu
}

$\mathrm{P}$ rzedmiotem analizy sa przedstawienia Oblicza Chrystusa: malowidła ścienne, z ok. 1350-1360 roku, z kamienicy przy ul. Żeglarskiej 17/19, I piętro, obecnie zatynkowane - (A) ${ }^{1}$, oraz malowidła ścienne, rok 1390, z prezbiterium kościoła św. Jakuba, ściana wschodnia i sklepienie) - $(B)^{2}$.

(A) Malowidła przy ul. Żeglarskiej (il. 1) skomponowane sa na płaszczyźnie leżącego prostokąta. Centrum zajmuje Oblicze Chrystusa - widoczne frontalnie, twarz z brodą i fragmentami wąsów ujęta symetrycznie, wokół głowy nimb krzyżowy. Wyraźnie zostały wyodrębnione szyja i ramiona, na które spływają włosy. Po lewej stronie stoi zwrócony w trzech czwartych

1 J. Domasłowski, Dom pray ul. Żeglarskiej 17/19, [w:] Malarstwo gotyckie w Polsce. Katalog zabytkón, red. A. S. Labuda i K. Secomska, t. 2, cz. 3, Warszawa 2004, s. 104; idem, Malarstwo ścienne, [w:] J. Domasłowski, A. Karłowska-Kamzowa, A. S. Labuda, Malarstwo gotyckie na Pomorzu Wschodnim, Warszawa-Poznań 1990, s. 10-58, rys. nr 1, s. 13-14; idem, Pomorze Wschodnie, [w:] Gotyckie malarstwo ścienne w Polsce, Seria Historia Sztuki, nr 17, red. A. Karłowska-Kamzowa, Poznań 1984, s. 121-162, rys. 32, s. 299; idem, Malowidła ścienne w toruńskich średniowiecznych wnetrzach mieszkalnych, „Rocznik Muzeum w Toruniu”, t. 7, 1982, s. 28-41; idem, Uwagi o programach ideowych i systemach dekoracyjnych gotyckich malowidet ściennych w budowlach swieckich na terenie Prus Krayżackich i Królewskich, [w:] Sztuka Pobrzeża Battyku, Materiały Sesji SHS, Gdańsk, listopad 1976, Warszawa 1978, s. 149-165.

2 J. Domasłowski, Kościót par. Nowego Miasta p.w. św. Jakuba, [w:] Malarstwo gotyckie w Polsce. Katalog rabytkón, red. A. S. Labuda i K. Secomska, t. 2, cz. 3, Warszawa 2004, s. $101-$ -103; idem, Malarstwo ścienne, s. 10-58; idem, Pomorze Wschodnie, s. 121-162; L. Krantz-Domasłowska, J. Domasłowski, Wyposażenie wnetrza, [w:] L. Krantz-Domasłowska, J. Domasłowski, Kościót śniętego Jakuba w Toruniu, „Zabytki Polski Północnej” 2001, nr 11, s. 69-137; M. Michnowska, Malowidła ścienne ₹. XIV w kościele św. Jakuba w Toruniu, „Teka Komisji Historii Sztuki" 1965, t. 3, s. 5-73. 
św. Jan Ewangelista - głowa otoczona nimbem, w lewej ręce trzyma kielich z wyraźnie widoczną Hostią, prawą ręką (z wyciagniętym palcem) wskazuje zarówno na Chrystusa, jak i na kielich. Po prawej stronie (we fragmentarycznie widocznej arkadzie) stoi św. Jan Chrzciciel. Twarz i korpus niezachowane, widoczne są fragmenty nimbu i włosów, bose stopy i włosiennica. Powyżej na lewo fragmenty architektury - maswerkowe okna (?). W dolnym pasie, poniżej wizerunków, namalowana kotara opadająca miseczkowato zaznaczonymi fałdami. Oblicze Chrystusa, wyraźnie większych rozmiarów, wydaje się aplikowanym elementem, jak gdyby „cytatem” odwołującym się do pewnego archetypu.

(B) Malowidła na wschodniej ścianie szczytowej (il. 3) powyżej okna środkowego - chusta w kształcie nieregularnego czworokata trzymana przez dwa klęczące anioły w szarozielonych szatach (duże zniszczenia warstwy malarskiej - wizerunek na chuście niewidoczny) (il. 2). Na sklepieniu (na wysklepkach powyżej) namalowano cztery cherubiny, adorujące chustę również w pozycji klęczącej, ze złożonymi modlitewnie rękami. Figury cherubinów nieco większych rozmiarów. Dwa cherubiny umieszczone symetrycznie nieco niżej odziane są w szarozielone szaty i maja cztery czerwone skrzydła. Pozostałe dwa, usytuowane nieco wyżej, mają czerwone suknie oraz szarozielone skrzydła. Poniżej, pod stopami cherubinów, banderole z zapisem inwokacji: Sanctus Sanctus Dominus Deus Sabaoth (początkowe litery).

Zagadnieniami rozpatrywanymi w niniejszej publikacji jest typ ikonograficzny wizerunku Oblicza Chrystusa, treści ideowe oraz funkcje, które można wiązać z tym zabytkiem. Literatura przedmiotu nie udziela odpowiedzi na pytania dotyczące wspomnianych powyżej kwestii. W najnowszych opracowaniach podaje się w wątpliwość sam typ (Veraicon?) wizerunku oblicza Chrystusa $-\mathrm{B}^{3}$. Nietypowe przedstawienie Oblicza Chrystusa z A już na etapie rozpoznania ikonograficznego wymaga odpowiedzi na pytanie, czy można go zaliczyć do przedstawień „nie ręką ludzką uczynionych”.

W celu właściwego rozpoznania ikonograficznego wizerunków A i B należy scharakteryzować typ acheiropoietos (Mandylion, Veraicon) ${ }^{4}$. Wie-

3 J. Domasłowski, Dom pray ul. Żeglarskiej 17/19, s. 102.

4 Na ten temat: H. Belting, Das Bild und sein Publikum im Mittelalter, Berlin 1981; idem, Obraz i kult, tłum. T. Zatorski, Gdańsk 2010; M. Büchsel, Die Entstehung des Christus por- 
rzono, że tego typu wizerunki powstały przez odbicie w cudowny sposób twarzy Chrystusa na chuście. Wyróżnić można dwie tradycje związane z powstaniem tego typu przedstawienia.

Najstarsza i pierwotna jest tradycja wschodnia. Pierwsza wzmianka o tego typu wizerunku z Edessy pochodzi z VI wieku i znajduje się w Kronice Ewagriusza. Kronikarz opisuje zarówno cudowne powstanie wizerunku, jak i cuda z nim związane. Przytacza legendarny przekaz, według którego Chrystus sam przyłożył chustę do twarzy, a odbity wizerunek przesłał królowi Edessy, Abgarowi. Wizerunek miał uleczyć chorego króla i uratować Edessę przed wrogimi wojskami perskimi w 544 roku. Wierzono, że obraz potrafi w cudowny sposób powielać się - keramidion ${ }^{5}$. W roku 944 relikwia została przewieziona przez cesarza Romana I do Konstantynopola i umieszczona jako Święty Mandylion w kaplicy pałacowej. Patriarcha Konstantynopola German I nazwał ten wizerunek Sudarium. Wizerunek przebywał w Konstantynopolu do 1204 roku. Opowieści o cudach związanych z Obliczem Chrystusa przyczyniały się do powielania wizerunku, którego liczne powtórzenia propagowały typ ikonograficzny powstały w kręgu sztuki wschodniej. Obrazowe powtórzenia nazywano na Wschodzie Mandylionem. Fundamentalnym wyróżnikiem typu Mandylion było ukazywanie na chuście Chwalebnego Oblicza Chrystusa bez oznak męki, bez zarysowanych szyi i ramion. Przykładami mogą być XII-wieczna ikona, Mandylion z Nowgorodu (il. 4) (1130-1200 r., Moskwa, Galeria Tretiakowska), obrazy w San Silvestro in Capite (do 1870 w posiadaniu klarysek, obecnie Rzym,

träts. Bildarchäologie statt Bildhypnose, Meinz am Rhein 2003; Veronika, Johannes H. Emminghaus], Lexikon für Theologie und Kirche, hrsg. J. Höfer, K. Rahner, Freiburg im Breisgau 1965, Bd. 10, s. 728-729; Veronika, Johannes H. Emminghaus], Lexikon der christlichen Ikonographie, hrsg. W. Braunfels, Rom-Freiburg 1976, Bd. 8, s. 543-544; A. Grabar, La Sainte Face de Laon. Le mandylion dans l' art. Orthodoxe, Praha 1931; Antlitz, heiliges [Adolf Katzenellenbogen], Reallexikon zur deutschen Kunstgeschichte, red. O. Schmitt, Bd. 1, Stuttgart 1937, s. 732-742; J. J. Kopeć, Meka Pańska w religijnej kulturze polskiego średnioniecz̧a, Textus et studia, t. 3, Warszawa 1975; K. Künstle, Ikonographie der christlichen Kunst, t. 1, cz. 2, Freiburg im Breisgau 1928, s. 443-444, s.589-592; J. Wilson, Całun Turyński, t. 1, tłum. A. Polkowski, b.m.w.1986.

5 Antlitz, heiliges [Adolf Katzenellenbogen], op. cit., s. 733.

${ }^{6}$ H. Belting, Das Bild und sein Publikum im Mittelalter, s. 180-183, il. 68 i 69; J. Kłosińska, Sztuka bizantyńska, Warszawa 1975, s. 205, il. 81. 
Watykan, kościół św. Piotra) i tzw. Obraz z Genui z kościoła San Bartolomeo degli Armeni (podarunek bizantyjskiego cesarza Jana V (1341-1391)7.

Mandylion wiazzano na Wschodzie $\mathrm{z}$ dogmatem o dwóch naturach Chrystusa. Ustalony na Soborze Chalcedońskim w 451 roku był on odpowiedzią na herezję monofizycką. Zarówno dogmat, jak i sam Mandylion były wykorzystywane w walce $\mathrm{z}$ ikonoklazmem ${ }^{8}$.

Tradycja zachodnia powstała poprzez asymilację i przekształcenia legend i wizerunku z tradycji wschodniej. Zmieniona wersja legendy, łączaca wizerunek Chrystusa z kobietą o imieniu Ber(o)nike lub Weronika, rozpowszechniana była na Zachodzie od VI wieku poprzez różne wersje tekstów (łacińska, koptyjska, syryjska) tzw. Akta Piłata. Cudowny obraz Oblicza Chrystusa na chuście, pozyskany od kobiety o imieniu Weronika, przywrócić miał tym razem zdrowie cesarza Tyberiusza. Postać Weroniki identyfikowano, opierając się na tekstach Nowego Testamentu z jedną z kobiet z kręgu Chrystusa ( k 23-27) lub z kobietą cudownie uzdrowioną z krwotoku przez Chrystusa (Mt 9,20; Mk 5,25-34; Łk 8,40).

Fundamentalnie zmieniona wersja legendy znajduje się w Biblii Rogera von Argenteuil (Bible en Francois, ok. 1300 r.). Veraicon został tu zwiazany z historią Męki Pańskiej. Nowa wersja legendy mówiła, że Weronika spotkała Chrystusa na Drodze Krzyżowej i współczując Jego męce, podała chustę dla otarcia potu i krwi. Na tej chuście pozostało odbicie zarysów twarzy Chrystusa. Treść legendy o Weronice w jej pierwotnej wersji już w XII wieku powiązano z relikwią chusty ze Świętym Obliczem, przechowywaną w rzymskiej Bazylice św. Piotra.

W Chronicon, napisanej w X wieku przez Benedykta do św. Andrzeja, mnicha z Soratte, znajduje się wzmianka o obecności tej relikwii w Bazylice św. Piotra. Relikwii przechowywanej w Rzymie oddawano cześć, kro-

7 M. Büchsel, op. cit., s. 115-117, il. 51 i 52; Antlitz, heiliges [Adolf Katzenellenbogen], op. cit., s. 733; K. Künstle, op. cit., s. 590.

8 Bilderstreit, [Karl Baus], Lexikon für Theologie und Kirche, hrsg. J. Höfer, K. Rahner, Freiburg im Breisgau 1958, Bd. 2, s. 461-463; M. Büchsel, op. cit., s. 95 i n. Das Konzil v. Chalkedon, [Alois Grillmeier], Lexikon für Theologie und Kirche, hrsg. J. Höfer, K. Rahner, Freiburg im Breisgau 1958, Bd. 2, s. 1006-1009; Monophysitismus, [Alois Grillmeier], Lexikon für Theologie und Kirche, hrsg. J. Höfer, K. Rahner, Freiburg im Breisgau 1962, Bd.7, s. $563-565$. 
nikarz notuje liczne dowody kultu, jakim otaczano ten wizerunek. W 1208 roku papież Innocenty III ustanowił coroczną uroczystą procesję ze Świętym Wizerunkiem, która praktykowano do pontyfikatu Klemensa V (1305-1314). Bonifacy VIII w końcu XIII wieku ustanowił odpusty związane z nawiedzeniem lub wykonaniem kopii Świętego Oblicza9.

Opisane praktyki sprzyjały zarówno pielgrzymkom do relikwii, jak i rozpowszechnianiu wizerunku Świętego Oblicza. Znane były licznie przywożone przez pielgrzymów z Rzymu tzw. Weroniki ${ }^{10}$. Rozprzestrzeniające się wizerunki Oblicza Chrystusa często nie były prawdziwymi i wiernymi kopiami rzymskiego oryginału.

W tradycji zachodniej nie ustalił się jeden, obowiązujący kanon wizerunku. Długo duże znaczenie miał wizerunek typu edesseńskiego. Artyści rzadko, i to z daleka, mogli oglądać relikwię ${ }^{11}$, zatem związki licznych kopii z oryginałem były natury ideowej, a nie formalnej. Szerzyły się różne warianty tego wizerunku. Europejscy artyści, miniaturzyści XIII-wieczni, malarze XIV i XV wieku nieznający rzymskiego Świętego Oblicza, tworzyli dość dowolne dzieła, których inspiracją były dostępne kopie lub legenda w jej pierwotnej wersji. Ta wersja opowieści, łącząca powstanie Veraiconu z okresem publicznej działalności Chrystusa, sprzyjała powielaniu wizerunku oblicza uduchowionego, bez oznak cierpienia i śladów męki niepowiązanego z pasja.

Przykładem wizerunku łączonego z Veraiconem rzymskim jest tzw. Obraz z Laon - Święte Oblicze, dar papieża Urbana IV z 1248 roku dla jego siostry, przeoryszy klasztoru Montreuil-les-Dames koło Laon (il. 7). Dzięki obrazowi klasztor stał się miejscem licznych pielgrzymek. A. Grabar uważa, że czczony tam obraz jest ikoną wykonaną w kręgu sztuki wschodniej $^{12}$. W XIII wieku pojawił się w tradycji zachodniej wizerunek Prawdziwego Oblicza Chrystusa, na którym widoczna jest również szyja i ramiona. Przykładem jest miniatura zamieszczona w Chronica Maiora, Matthew Paris,

9 Zob. przyp. 4.

10 H. Belting, Das Bild und sein Publikum im Mittelalter, s. 34-36, przyp. 13.

11 K. Künstle, op. cit., s. 592.

12 A. Grabar, op. cit., s. 15. 
po 1245 roku (il. 6) (Cambridge, Corpus Christi College, Ms. 16., Matthew Paris, Chronica Maiora, fol. 49 v. $)^{13}$.

Wynikiem długotrwałego procesu jest powstanie w tradycji zachodniej typu pasyjnego Prawdziwego Oblicza. Twarz Chrystusa jest w nim naznaczona cierpieniem, krwawymi ranami, na Jego głowie zaś umieszczono koronę cierniowa. Przykładem może być Veraicon ze Śląska, ok. 1450 roku (il. 5) (pochodzi z kościoła NMP. w Legnicy, obecnie Muzeum Narodowe Wrocław $)^{14}$. W ciągu XIII i XIV wieku poszerza się kontekst przedstawieniowy - pojawiają się anioły trzymające chustę. Zdarza się, że chustę trzymają i adorują także święci bądź fundatorzy.

Dla zinterpretowania toruńskich wizerunków, szczególnie tego z kościoła św. Jakuba, konieczne jest uwzględnienie treści ideowych wizerunku Chrystusa na chuście. Wizerunek ten pojawia się w wyraźnym kontekście eucharystycznym - w mszałach, przy słowach konsekracji. Przykładem jest Mszał Śląski, 3. ćw. XIV w. (Missale, Wrocław, BU, sygn. N 1134) ${ }^{15}$. W tekście kanonu mszy, przy słowach konsekracji, pojawia się na marginesie Oblicze Chrystusa.

Wizerunek Veraiconu stosowano podobnie jako dekorację nisz sakramentalnych. Przykładem może być sakrarium na północnej ścianie chóru kościoła w Jasionej (3. ćw. XIV w. ${ }^{16}$. Wykorzystywano także wizerunki Oblicza Chrystusa na ścianach wschodnich, w prezbiteriach, powyżej ołtarza. Jako przykład można wskazać ścianę wschodnią kościoła w Czchowie (2. poł. XIV w. $)^{17}$. Oblicze Chrystusa trzymaja tam dwa anioły.

Wizerunek Oblicza Chrystusa na Chuście (a więc Wizerunek Prawdziwy) w kontekście słów konsekracji, ołtarza bądź sakrarium, staje się wizualizacją dogmatu o transsubstancjacji i rzeczywistej obecności Chrystu-

${ }_{13}$ Antlitz, heiliges, [Adolf Katzenellenbogen], op. cit., s. 737, il. nr 1. Ilustracja nr 6 z http://commons.wikimedia.org/wiki/Category:Historia_Major_of_Matthew_Paris (3.02.2013)

14 A. Ziomecka, Sztuka na Ślasku. Katalog z̧biorón, Muzeum Narodowe we Wrocławiu, Wrocław 2003, s. 261-262, kat. 47, il. 47.

15 A. Karłowska-Kamzowa, Malarstwo ślaskie 1250-1450, Wrocław-Warszawa 1979, s. $27,111$.

16 Ibidem, s. 19.

17 J. Gadomski, Malowidła ścienne ₹ XIV wieku w Czchowie, „Folia Historiae Artium” 1965, t. 2, s. 5-45, 28-32, il. 17; przyp. 99 ze s. 31. 
sa w Eucharystii (IV Sobór Laterański 1215 r.) ${ }^{18}$. Trzymające chustę anioły stają się aniołami mszy, a twarz Chrystusa symbolizuje przemienioną Hostię spoczywająca na korporale ${ }^{19}$.

Analiza przytoczonych wyżej przykładów pozwala uznać, że również w Toruniu, w kościele św. Jakuba zastosowano tego typu przedstawienie w przestrzeni sakralnej powyżej ołtarza, aby wizualizować sakrament Eucharystii. Tezę o Veraiconie w kościele św. Jakuba uprawdopodabnia porównanie analizowanego wizerunku z przedstawieniem w kościele św. św. Piotra i Pawła w Hosinie (4. lub 3. dziesięciolecie XIV w., il. 8) ${ }^{20}$. Powyżej niszy apsydy na ścianie wschodniej kościoła w Hosinie dwa anioły trzymaja chustę z widocznym, acz również nieco zniszczonym Obliczem Chrystusa. Istnieje wyraźne podobieństwo rozmieszczenia aniołów w kościele św. Jakuba i kościele w Hosinie.

Typ wizerunku na chuście w kościele św. Jakuba jest trudny do zrekonstruowania. Można jednak wskazać przykłady wcześniejszych realizacji tego tematu na terenie Pomorza Wschodniego. Przytoczę dwa wizerunki z zakresu malarstwa miniaturowego w Graduale Pelplińskim, lata 70. XIV wieku, pracownia pelplińska (Graduale de tempore et sanctis, Pelplin, Bibloteka Sem., sygn. L 13). Miniatura na karcie 92 (il. 9a) przedstawia Veraicon trzymany przez biskupa. Przedstawienie to jest przykładem, że ryt procesji ze Świętym Obliczem był znany szeroko poza Italia. Druga miniatura, z karty 17 (il. 9b), zdobi tekst liturgiczny pierwszej niedzieli po święcie Trzech Króli ${ }^{21}$. Oba Oblicza (il. 9a, 9b) są bez śladów męki i dowodzą, że

18 Zob. H. Turska, Odzwierciedlenie doktryny eucharystycznej Kościoła katolickiego w średniowiecznej sztuce polskiej - wybrane prayktady, „A U N C. Zabytkoznawstwo i Konserwatorstwo” XLII, Toruń 2011, s. 431-467, szczególnie przyp. 1 i 2 ze s. 432.

19 A. S. Labuda, Wroctawski ottarz św. Barbary i jego twórcy, Poznań 1984, s. 172; Engel [Karl-August Writh], Reallexikon zur deutschen Kunstgeschichte, red. K. A. Writh, Bd.5, Stuttgart 1967, s. 341-555, 419-423.

20 Gotická nastěnná malba v zemích českéch, I ,1300-1350, red. J. Pešina, Praha 1958, s. 97-98, 251-258; il. 136; M. Michnowska, op. cit., s. 14.

${ }^{21}$ G. Jurkowlaniec, Graduale de tempore et de sanctis, [w:] Malarstwo gotyckie w Polsce. Katalog zabytkón, red. A. S. Labuda i K. Secomska, Warszawa 2004, t. 2, cz. 3, s. 380-382, il. 1267; A. Karłowska-Kamzowa, Środowiska miejscowe, [w:] J. Domasłowski, A. Karłowska-Kamzowa, A. S. Labuda, Malarstwo gotyckie na Pomorzu W schodnim, Warszawa-Poznań 1990, s. 193-218, s. 195, il. 108; J. J. Kopeć, op. cit., s. 364. 
tego typu warianty były stosowane w XIV wieku na Pomorzu Wschodnim. Istotna może być obecność tego typu wzorów obrazowych w tekstach służących liturgii mszy. Miniatury w kodeksach były bowiem dość powszechną drogą przenoszenia nowych wzorów.

Dodatkowym argumentem, przemawiającym za tym, że przedstawienie B jest wizualizacja liturgii mszy, moga być słowa inwokacji, umieszczone pod stopami cherubinów (patrz opis B).

Analiza wizerunku (B) w kościele św. Jakuba sugeruje, że w Toruniu już w końcu XIV wieku zaadaptowano wczesną tradycję zachodnia, odnoszącą się do obrazowania dogmatów ustalonych na IV Soborze Laterańskim o transsubstancjacji i rzeczywistej obecności Chrystusa w Eucharystii. Zastosowana wizualizacja sakramentu Eucharystii, twarz Chrystusa na chuście równa się Hostia na korporale, mogła być skuteczną formą przekazywania trudnych treści związanych z sakramentem ołtarza ${ }^{22}$.

Wizerunek z ul. Żeglarskiej (A) również wymaga przyporządkowania do jednego z typów ikonograficznych. Odbiega od powszechnie przyjętych przedstawień „nie ręką ludzką uczynionych”. Kluczowe dla identyfikacji wizerunku A wydaje się przedstawienie we wspominanej już Chronica Maiora (il. 6). Wizerunek oblicza w kronice został umieszczony w tekście, który opowiada o cudzie, jaki zdarzył się w Rzymie w związku z relikwią chusty. W trakcie procesji, prowadzonej w 1216 roku przez papieża Innocentego III, Veraicon obrócił się na chuście. Pod wrażeniem cudu papież napisał modlitwę, do której dołączył odpust. Cud uważano za potwierdzenie autentyczności relikwii. Matthew Paris pisze, iż wielu uczyło się modlitwy na pamięć i ,aby wzbudzić w sobie jeszcze większe nabożeństwo, ilustrowało ją w taki oto sposób sposób ${ }^{23}$ " - w tym miejscu autor zamieszcza wizerunek Oblicza Chrystusa (il. 6). Sądzić zatem można, że takie nietypowe Oblicze Chrystusa (widoczna szyja i ramiona) w XIII wieku identyfikowano i rozumiano jako autentyczne oblicze Chrystusa „nie ręką ludzką uczynione".

22 Zob. H. Belting, Das Bild und sein Publikum im Mittelalter, s. 91, przyp. 35 i n.

23 Za H. Belting, Obraz $i$ kult, s. 612; ważna jest także uwaga H. Beltinga z Das Bild und sein Publikum im Mittelalter: „Das Bild [Veronica] ist also vom öffentlichen in den privaten Kult gewandert” s. 104 także s. 200 i n. 
Poza tym za interpretowaniem wizerunku A jako Prawdziwego Oblicza Chrystusa przemawia obecność św. Janów - Chrzciciela i Ewangelisty ${ }^{24}$. Dla zrozumienia istoty kontekstu wydaje się niezbędne sięgnięcie do odpowiednich fragmentów Ewangelii św. Jana (J 1,26; 1,27; 1,29-30; 1,33-34; 1,36) (J 6,$41 ; 6,48 ; 6,50 ; 6,51 ; 6,53-57 ; 6,59)$

Jan 1, 26 Jan im tak odpowiedział: „Ja chrzczę wodą. Pośród was stoi Ten, którego wy nie znacie".

To Ten, który przyjdzie po mnie...

29 Nazajutrz zobaczył Jezusa, nadchodzącego ku niemu, i rzekł: „Oto Baranek Boży, który gładzi grzechy świata".

36 i gdy zobaczył przechodzącego Jezusa, rzekł: „Oto Baranek Boży”.

Jan, 6

49 Ojcowie wasi jedli mannę na pustyni i pomarli. 50 To jest chleb, który z nieba zstępuje: kto go spożywa, nie umrze. 51 Ja jestem chlebem żywym, który zstapił z nieba. Jeśli kto spożywa ten chleb, będzie żył na wieki. Chlebem, który ja dam, jest moje ciało za życie świata. 52 Sprzeczali się więc między sobą Żydzi mówiąc: „Jak On może nam dać [swoje] ciało do spożycia?” 53 Rzekł do nich Jezus: „Zaprawdę, zaprawdę, powiadam wam: Jeżeli nie będziecie spożywali Ciała Syna Człowieczego i nie będziecie pili Krwi Jego, nie będziecie mieli życia w sobie. 54 Kto spożywa moje Ciało i pije moją Krew, ma życie wieczne, a Ja go wskrzeszę w dniu ostatecznym"²5.

Teksty ewangeliczne odnoszą się do PRAWDZIWEGO Mesjasza i PRAWDZIWEGO Chleba Eucharystycznego. Tylko Veraicon miał oficjalnie poświadczony walor prawdziwości. O kontekście eucharystycznym dodatkowo świadczy kielich z Hostia trzymany w rękach św. Jana Ewangelisty. Święty wskazuje ręką zarówno na Veraicon, jak i na kielich z Hostią - jak gdyby potwierdzał tożsamość ciała sakramentalnego i wcielone-

${ }^{24}$ K. Künstle, Ikonographie der christlichen Kunst, t. 2, cz. 2, Freiburg im Breisgau 1926, s. $331-347$.

25 Cytaty biblijne wg Biblia Tysiąclecia, wyd. 4, Pallotinum, red. ks. K. Dynarski, Poznań 1991. 
go. Można przypuszczać, jak sugeruje Jerzy Domasłowski, że kontekstem mogła być także adoracja Oblicza, „motyw często łączony z Eucharystia”, kult relikwii2 ${ }^{26}$.

Wydaje się jednak, że zasadnicze znaczenie miał kontekst eucharystyczny (Chleb Żywy, dający Życie Wieczne). Potwierdzić to można, porównując przedstawienia przy ul. Żeglarskiej z wizerunkami św. Jana Ewangelisty i św. Jana Chrzciciela na ścianie wschodniej prezbiterium kościoła św. św. Janów w Toruniu. Z kontekstu topograficznego wynika, że miejsce ołtarza w kościele zajmuje na malowidle (A) wizerunek Oblicza Chrystusa (widoczna poniżej tkanina może być także nawiązaniem do mensy ołtarzowej). Sugestia Jerzego Domasłowskiego dotyczaca czasu powstania malowideł A - ok. 1350-1360 - i w kościele św. św. Janów (może nieco późniejsze) - ok. 1360 roku $^{27}$ otwiera pole do dyskusji o wzajemnej inspiracji.

W niewielkiej odległości czasowej oraz przestrzennej na terenie Torunia (Stare i Nowe Miasto) zastosowano dwa typy Prawdziwego Oblicza Chrystusa - Veraicon. Pierwsze z nich (wizerunek A - ul. Żeglarska 17/19) reprezentuje bardzo wczesny typ wizerunku, występujący w tradycji zachodniej, drugie (wizerunek B - kościół św. Jakuba) - Oblicze na chuście trzymanej przez anioły - reprezentuje przemiany formy i treści ideowych zachodzące w sztuce Zachodu.

O ile wizerunek A wiązać można $z$ adoracją i dewocją (raczej prywatna), o tyle drugi - wizerunek B - związany jest z publiczną liturgia ołtarza. Każdy z typów wizerunku został wybrany do pełnienia innej funkcji.

\section{Summary}

\section{Veraicon in Medieval Torun}

The subject of the analysis are the images of the Faces of Jesus: wall paintings, from around 1350-1360, from the tenement house at 17/19 Żeglarska Street, 1-st

\footnotetext{
26 J. Domasłowski, Malowidła ścienne w torunskich średniowiecznych wnetrzach mieszkalnych, s. 30; idem, Malarstwo ścienne, s. 13.

27 J. Domasłowski, Uwagi o programach ideonych i systemach dekoracyjnych..., s.162; idem, Wyposażenie wnetrza, [w:] Bazylika katedralna Świetych Janów w Toruniu, Zabytki Polski Północnej, nr 12, red. M. Biskup, Torun 2003, s. 109-228, s. 114-115, il. 45.
} 
floor, currently plastered - (A), and wall paintings from St. Jacob's Church ,1390, the presbytery (the eastern wall and the vault) - (B).

The article presents the origin of the legend, historical message and the iconographic tradition of "archeiropoietos" images - not made by a human hand. The article describes and presents the oldest eastern tradition which created the iconographic canon of Mandylion image (Glorious Face of Jesus Christ). The study also contains ideological content connected, in the East, with this type of image. The article also analyses the formation of the western type of Veraicon, emphasising assimilation and conversion of legends and iconography taken from the East. The study indicates changes which led to the creation of the passion Face of Jesus. Different variations of Veraicon were discussed with the emphasis on the lack of one canonical representation in western art. New ideological content was stressed including the image of the Face of Jesus Christ in western art.

The article linked the representations $\mathrm{A}$ and $\mathrm{B}$ with adequate variants of the Face of Jesus appearing in Europe.

Concluding, it should be stated that, in the insignificant time and space gap, on the territory of Torun (Old Town and New Town), two different types of the Real Face of Jesus - Veraicon - were applied. The first of them (image A 17/19 Zeglarska Street) represents a very early type in the western tradition, the second one (the image B, St. Jacob's Church) - The Face on the Veil held by Angels represents transformations of the form and the ideological content taking place in the art of the West.

As long as the image A may be connected with adoration and bigotry (rather of private nature), the second image B is connected with public altar liturgy.

Each type of the image, representing a different variant of Veraicon, was selected to perform a different function. 


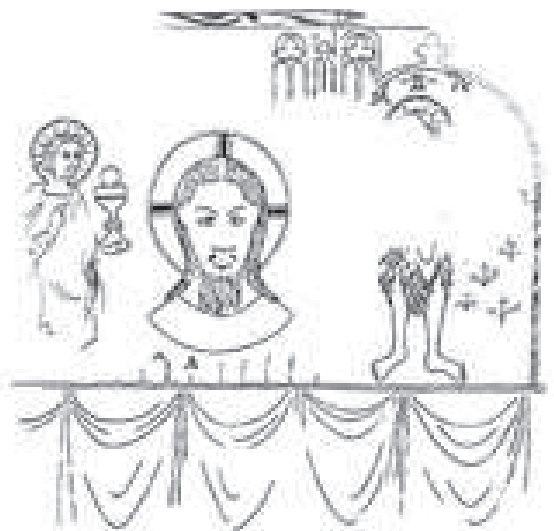

Il. 1. Malowidła ścienne, ok. 1350-1360 r., Toruń, ul. Żeglarska 17/19, fot. za Domasłowski 1984, rys. 32 


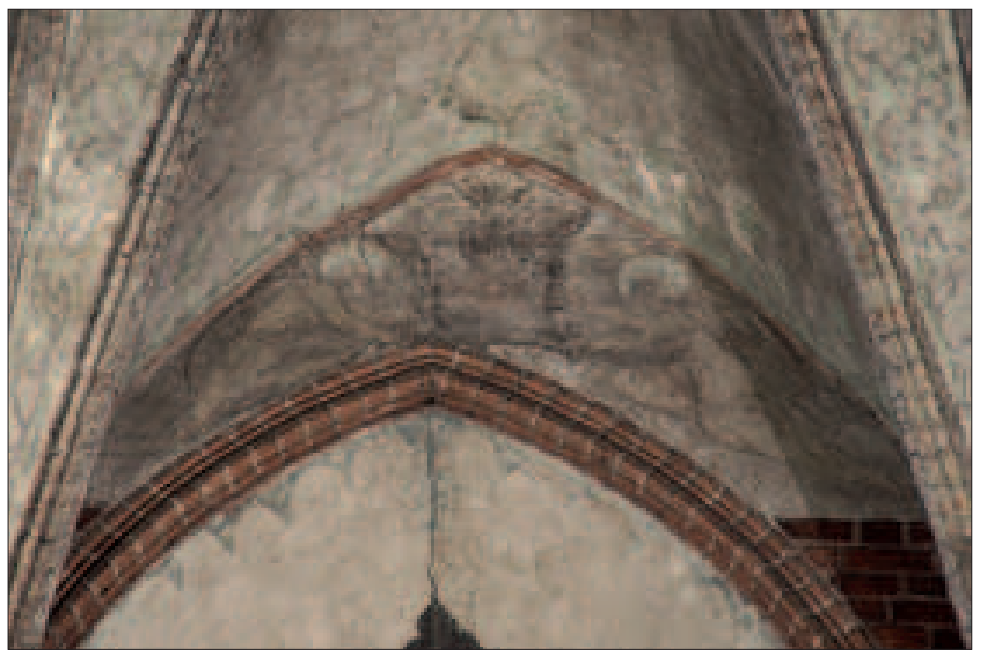

Il. 2. Malowidła ścienne, Veraicon trzymany przez dwa anioły, ok. 1390 r., Toruń, kościół św. Jakuba, fot. Marian Kosicki

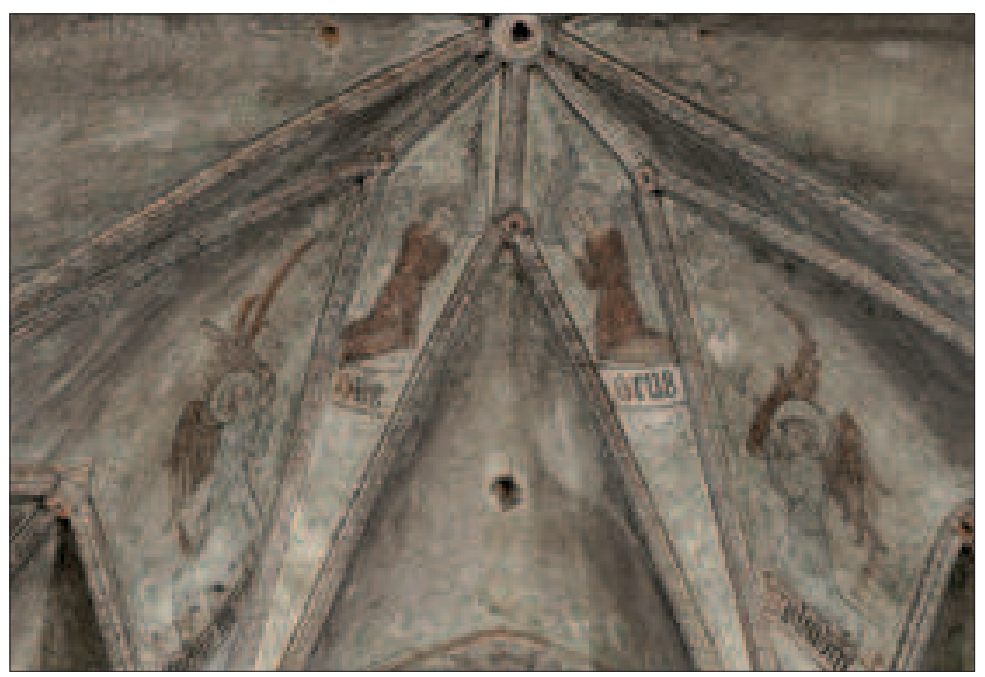

Il. 3. Malowidła ścienne (ściana wschodnia, sklepienie) ok. 1390 r., Toruń, kościół św. Jakuba, fot. Marian Kosicki 


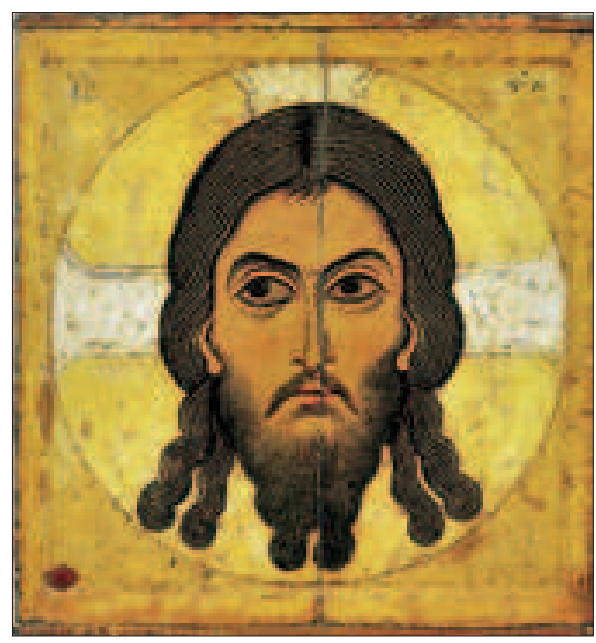

Il. 4. Ikona, Mandylion z Nowgorodu, k. XII w., Moskwa, Galeria Tretiakowska, dostęp w Internecie: http://www.icon-art. info/masterpiece.php?lng=de\&mst_id $=141$ (3.02.2013)

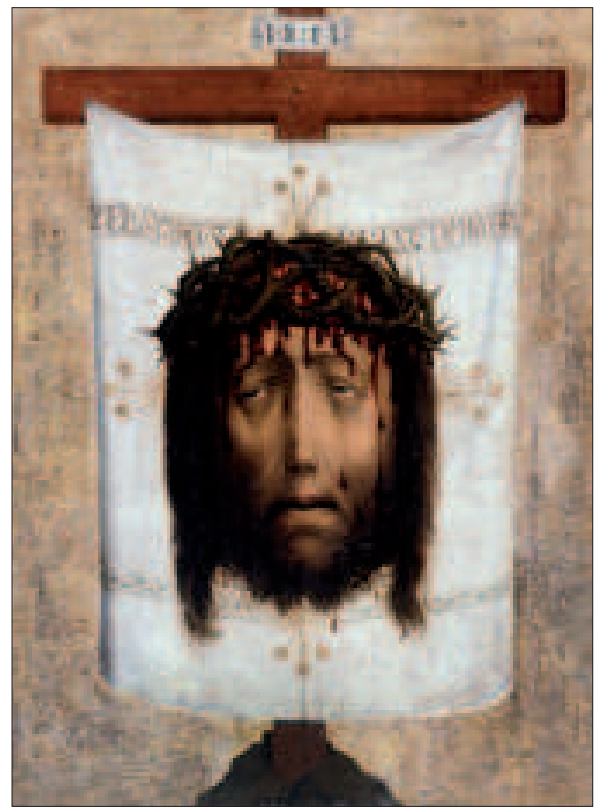

Il. 5. Obraz na desce, Veraicon z Legnicy, ok. 1450 r., Wrocław, Muzeum Narodowe, fot. za Ziomecka 2003, il. 47 


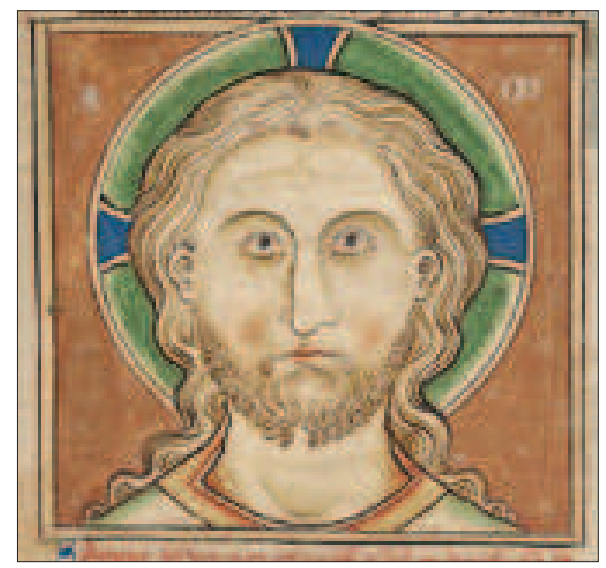

Il. 6. Miniatura w Chronica Maiora po 1245 r., Cambridge, Corpus Christi College, dostęp w Internecie; http://commons.wikimedia.org/ wiki/Category:Historia_Major_of_Matthew_ Paris (3.02.2013)

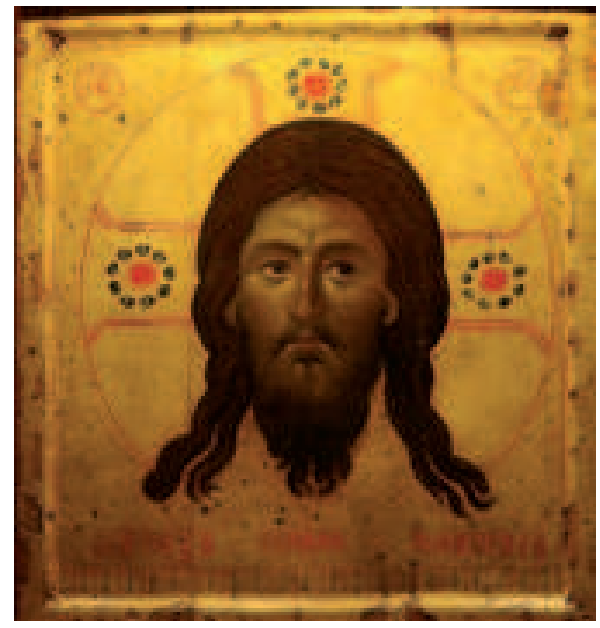

Il. 7. Ikona, Święte Oblicze z Laon, XIII w., Laon, katedra, dostęp w Internecie; http:// sosreb.wordpress.com/2012/09/ (3.02.2013) 


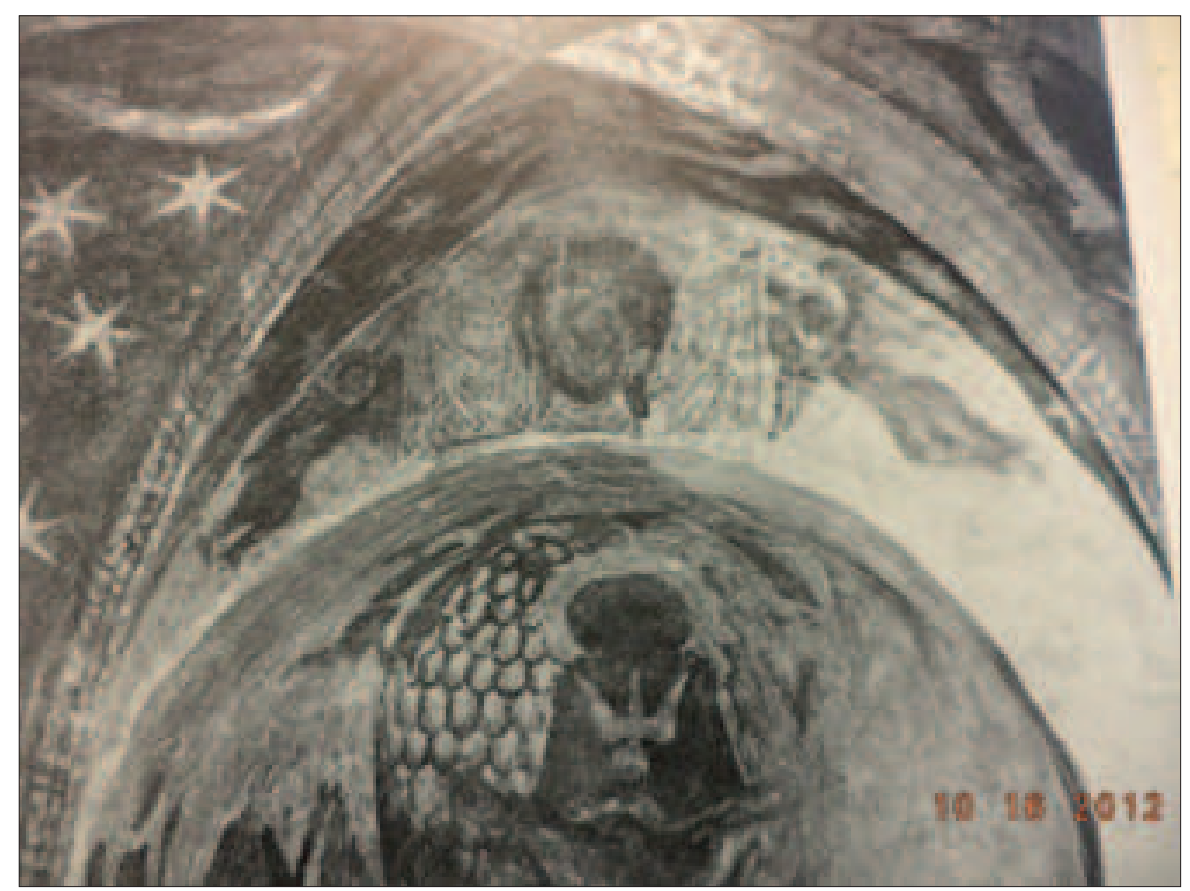

Il. 8. Malowidła ścienne, powyżej apsydy, 3 lub 4 ćw. XIV wieku, Hosin, kościół św. św. Piotra i Pawła, fot. za Gotická nastěnná malba v zemích českých, I, 1300-1350, 1958, il. 136 


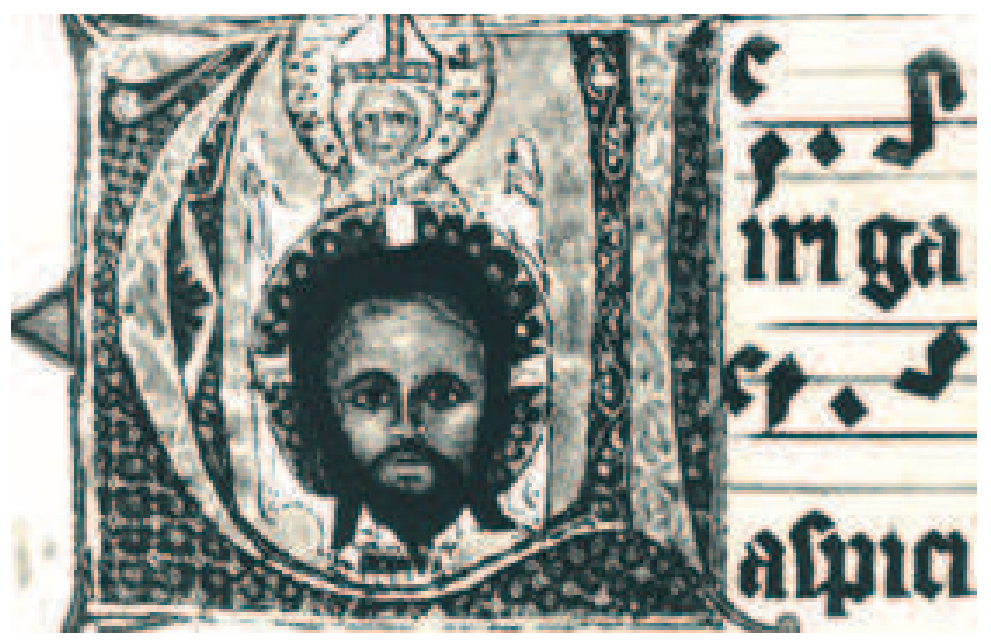

Il. 9a. Miniatura, Veraicon trzymany przez biskupa, lata 70. XIV wieku, Graduał Pelpliński, Pelplin, Biblioteka Seminarium, fot. za Karłowska-Kamzowa 1990, il. 108

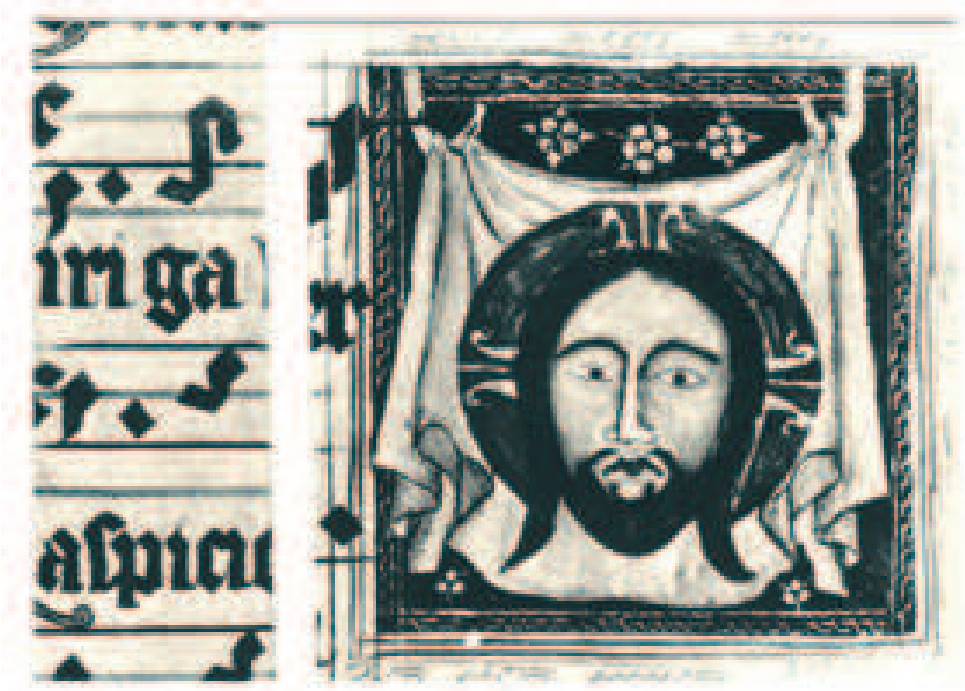

Il. 9b. Miniatura, Veraicon, lata 70. XIV wieku, Graduał Pelpliński, Pelplin, Biblioteka Seminarium, fot. za Karłowska-Kamzowa 1990, il. 108 